1. 1 th of an inch the focal length of the convex and concave surfaces under operation.

Although I have heretofore described the cellular casting as having a flat face, it wlll be obvious that if made into a concave corresponding with the intended focal length of the reflector that much thinner sheets of glass than those before named may be cmployed by first bending them to the required curve and fitting them by grinding to the concave iron surface, so that a glass reflector can on this principle be made just as large as a plateglass manufacturer can produce an ordinary thin plate.

A description of the novel arrangements which I employ for grinding and polishing the spherical concave reflector, and its conversion into a paraboloid of revolution would carry me far beyond the already too lengthy remarks. I have made, and which had for their primary object simply to show that we may still have good reason to hope that silver-on-glass reflectors of large diameters are within our reach.

Denmark Hill, January 21

\section{A Telephone Without Magnetism}

For some time past I have been experimenting with the view of transmitting articulate sounds through wires without the aid of electricity or magnetism.

I have now been quite successful, my experiments proving that the sounds of the human voice can be carried by vibrations through considerable lengths of wire.

Last night conversation was carried on with ease between four incividuals, situated in different rooms. Piano music, singirg, laughing, and breathing, were all clearly transmitted to the ear.

The whole distance would be about fifty yards.

The communication was effected by means of a mouth-piece with a vibrating disc in connection with the wire.

Glasgow

W. J. Millar

\section{Change of Habits in Toads}

WHile prosecuting my field-work as Palgentologist of the United States Geological Survey of the Territories, under the direction of Prof. F. V. Hayden, in Colorado, during last season, I had the opportunity to make some very interesting observations in relation to a change of habits in the common toad (Bufo americana). The district referred to is that portion of the great plains which lies immediately adjacent to the eastern base of the Rocky Mountains, and which is traversed by the South Platte River and its tributaries there.

The valleys of these streams are broad and shallow, and the streams heading in the immediately adjacent mountains have an abundant flow of water; so that large tracts of land in all those valleys have been brought under cultivation by irrigation. Irri. gation is necessary in all that region, for it lies within that portion of the United States domain upon which the annual rainfall is insufficient for the purposes of agriculture.

With the irrigation of the land came increased and perennial vegetation - with that came increased insect-life, and with that an increase of birds and toads. The irrigating ditches are everywhere numerous, and during the season of growing crops they are frcquently visited by men to regulate the flow of water to the land.

This and other circumstances disturb the toads that frequent the shades of the herbage which grows upon the borders of the water. It is no uncommon thing for toads as well as frogs, to jump into the water when disturbed, but the habit of the former is to make a shallow dive, rise immediately to the surface, and swim upon it by a sweeping curve to the shore again, not resting until the brink is gained, upon which they tarry a while before coming upon the land.

Frogs, on the contrary, when disturbed, make a strong dive directly to the bottom, upon which they lie prone, with the legs flexed against the body, and into the mud of which they settle themselves a little. Here they remain and exhaust the patience of one who may attempt to wait for them to rise. Now the toads in this irrigated region have adopted,precisely these common habits of the frogs when disturbed upon the borders of the ditches, as I repeatedly witnessed. I regard this as the resumption of an instinctive trait that has been potentially transmitted from a former race of Anourans that were less differentiated than frogs and toads are now from each other; and that the lately introduced change of physical conditions in the region has caused the toads to resume habits which the frogs have never abandoned

Washington, D.C., January 6

\section{Talking Photographs}

THE article from the Scientific American on the phonograph which is quoted in NATURE, vol. xvii. p. rgo, concludes as follows :- "It is already possible, by ingenious optical contrivances, to throw stereoscopic photographs of people on screens in full view of an audience. Add the talking phonograph to counterfeit their voices and it would be difficult to carry the illusion of real presence much further."

Ingenious as this suggested combination is, I believe $I$ am in a position to cap it. By combining the phonograph with the kinesigxaph I will undertake not only to produce a talking picture of Mr. Gladstone which, with motionless lips and unchanged expression shall positively recite his latest anti-Turkish speech in his own voice and tone. Not only this, but the life-size photograph itself shall move and gesticulate precisely as he did when making the speech, the words and gestures corresponding as in real life. Surely this is an advance upon the conception of the Scientific Anterican!

The mode in which I effect this is described in the acconipanying provisional specification, which may be briefly summed up thus: Instantaneous photographs of bodies or groups of bodies in motion are taken at equal short intervals--say quarter or half seconds-the exposture of the plate occupying not more than an eighth of a second. After fixing, the prints from these plates are taken one below another on a long strip or ribbon of paper. The strip is wound from one cylinder to another so as to cause the several photographs to pass before the eye successively at the same intervals for time as those at which they were taken.

Each picture as it passes the eye is instantaneously lighted up by an electric spark. Thus the picture is made to appear stationary while the people or things in it appear to move as in nature. I need not enter more into detail beyond saying that if the intervals between the presentation of the successive pictures are found to be too short the gaps can be filled up by duplicates or triplicates of each succeeding print. This will not perceptibly aiter the general effect.

I think it will be admitted that by this means a drama acted by daylight or magnesium light may be recorded and reacted on the screen or sheet of a magic lantern, and with the assistance of the phonograph the dialogues may be repeated in the very voices of the actors.

When this is actually accomplished the photography of colours will alone be wanting to render the representation absolutely complete, and for this we shall not, I trust, have long to wait.

WORDSWORTH DONISTHORPE

Prin:e's Park, Liverpool, January I2

\section{Sun-spots and Terrestrial Magnetism}

I BEG to direct Prof. Piazzi Smyth's attention to an article in the Anmurire du Burcau des Longitudes for 1878 by M. Faye, entitled "La Méiéorologie Cosmique," in which this distinguished as:ronomer and meteorologist says :- "La période des taches, portée à $I I^{\text {ans. }} \mathrm{I}$ par $M$. Wolf n'étant pas égale à celle des variz. tions magnétiques ( $\mathrm{ro}^{\mathrm{ans}} \cdot 45$ ), ces deux phénomènes n'ont aucun rapport enire eux." It thus appears rather premature to suppose that the sun-spot cycle and the terrestrial magnetic diurnal oscillation cycle are intimately connected.

Greenwich, January 2 I

\section{Great Waterfalls}

IN reply to Mr. Guillemard's inquiry in NATURE (vol. xvii. p. 22I) he will find some account of the Kávari or Cauvery Falls in the "Mysore Gazetteer," recently:compiled under orders of the Indian Government, vol. ii. pp. 27 1-273 (Bangalore, I876). A copy is doubtless to be seen at the India Office Library.

Edinburgh, Jantary $2 \mathrm{l}$

W. W. HUNTER

\section{Mechanical Analysis of the Trevelyan Rocker}

ALMOST every physical cabinet possesses one of Trevelyan's rockers, and yet it is rare to find one which always works well and gives complete satisfaction. Some two years ago having experienced this diffeculty in New York, where I was then Professor of Physics, I requested Mr. Robert Spice, F.C.S., of 230, Bridge Street, Brooklyn, U.S., a very skilful constructor of acoustic instruments, and a thorough physicist, to make for me several of these rockers and asscertain, if possible, the conditions 